\title{
Venous sinus injuries are common with occipital skull fractures
}

\author{
Susan Hendrickson ${ }^{1,2^{*}}$, Srinivas Murahari ${ }^{1,2}$, John Scotter ${ }^{1,2}$, Eilka Kashef ${ }^{1,2}$, Bryn Jones $^{1,2}$, Mark Wilson ${ }^{1,2}$ \\ From London Trauma Conference 2013 \\ London, UK. 10-13 December 2013
}

\section{Introduction}

Traumatic cerebral venous sinus injuries are usually managed conservatively, however sinus thrombosis and obstruction can result in refractory intracranial hypertension.

\section{Methods}

We retrospectively analysed CT venograms performed on 29 patients who had sustained a skull fracture that crossed a venous sinus at a London Major Trauma Centre.

\section{Results}

18 of the 29 patients studied had either venous sinus thrombosis (14) or significant sinus caliber compromise
(+/- thrombosis). Three mechanisms of sinus injury were noted in this group (Figure 1). A) Displaced fracture restricting sinus caliber; B) periosteal or extradural haematoma compressing the sinus and c) reactionary sinus thrombosis to an undisplaced overlying fracture.

\section{Conclusions}

CT Venography should be considered in patients with fractures overlying a venous sinus especially in cases with refractory or disproportionate intracranial hypertension or headache out of keeping with imaging appearances. We demonstrate different types of injury and management options.

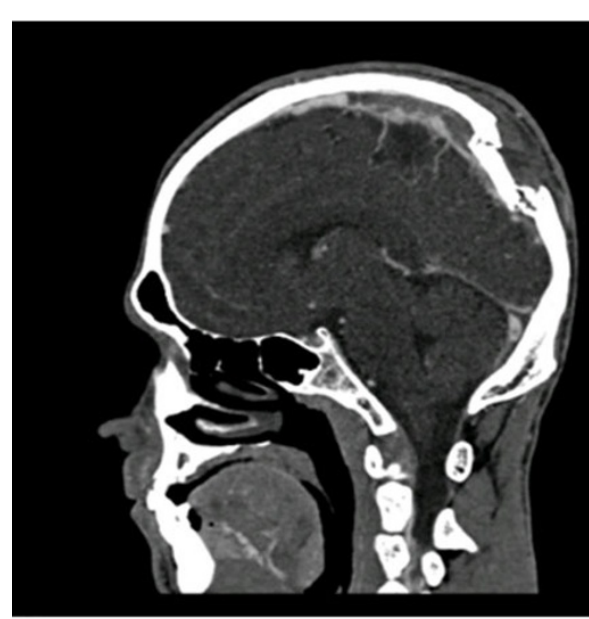

A)

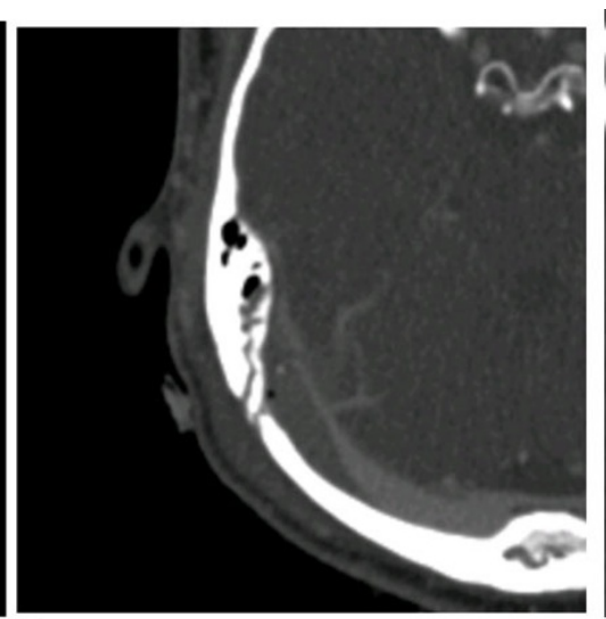

B)

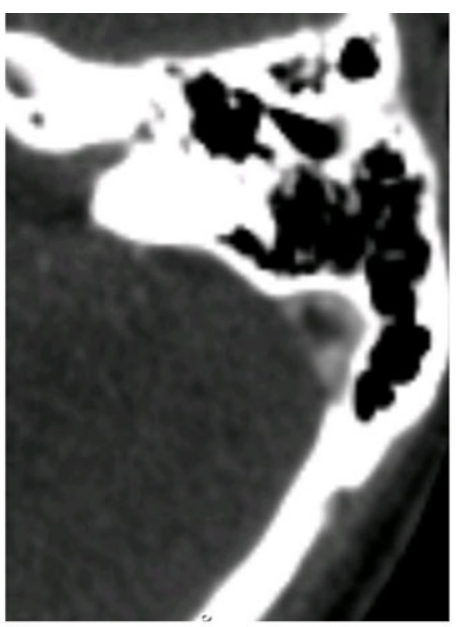

C)

Figure 1 A) Displaced fracture causeing sagittal sinus thrombosis; B) Periosteal haematoma compressing right transverse sinus; C) Right Sigmoid Sinus thrombus forming under undisplaced right occipital / base of skull fracture.

'London's Air Ambulance, London, UK

Full list of author information is available at the end of the article 


\section{Authors' details}

'London's Air Ambulance, London, UK. Pan London Neurotrauma Group,

London, UK.

Published: 7 July 2014

doi:10.1186/1757-7241-22-S1-08

Cite this article as: Hendrickson et al: Venous sinus injuries are common with occipital skull fractures. Scandinavian Journal of Trauma, Resuscitation and Emergency Medicine 2014 22(Suppl 1):O8.

Submit your next manuscript to BioMed Central and take full advantage of:

- Convenient online submission

- Thorough peer review

- No space constraints or color figure charges

- Immediate publication on acceptance

- Inclusion in PubMed, CAS, Scopus and Google Scholar

- Research which is freely available for redistribution

Submit your manuscript at www.biomedcentral.com/submit 